\title{
Cholelithiasis in Children with Sickle Cell Anaemia: A Cross-Sectional Analysis from Northeast Nigeria
}

\author{
Ayomikun Ajani1 ${ }^{*}$, Iliya Jalo ${ }^{1,2}$, Suleiman Tanimu Saad ${ }^{3}$ \\ ${ }^{1}$ Department of Paediatrics, Federal Teaching Hospital (FTH), Gombe, Nigeria \\ ${ }^{2}$ Department of Paediatrics, College of Medical Sciences, Gombe State University, Gombe, Nigeria \\ ${ }^{3}$ Department of Radiology, Federal Teaching Hospital (FTH), Gombe, Nigeria \\ Email: *ayomikuna2000@yahoo.com
}

How to cite this paper: Ajani, A., Jalo, I. and Saad, S.T. (2019) Cholelithiasis in Children with Sickle Cell Anaemia: A Cross-Sectional Analysis from Northeast Nigeria. Open Journal of Pediatrics, 9, 75-88. https://doi.org/10.4236/ojped.2019.91008

Received: January 29, 2019

Accepted: March 19, 2019

Published: March 22, 2019

Copyright ( 2019 by author(s) and Scientific Research Publishing Inc. This work is licensed under the Creative Commons Attribution International License (CC BY 4.0).

http://creativecommons.org/licenses/by/4.0/ (c) (i) Open Access

\begin{abstract}
Background: Nigeria contributes $30 \%$ to the global sickle cell anaemia burden. Cholelithiasis occurs commonly in children with sickle cell anaemia and may remain undiagnosed, mimic abdominal vaso-occlusive crises or become complicated by calculus cholecystitis. Early identification of children with sickle cell anaemia who have Cholelithiasis reduces the chances of misdiagnosis, mistreatment and improves outcomes. There is limited knowledge about the prevalence of Cholelithiasis among Nigerian children with sickle cell anaemia. The present study aimed to determine the prevalence of Cholelithiasis in children with sickle cell anaemia in Gombe, northeast Nigeria. Methodology: This was a cross-sectional analysis of children with sickle cell anaemia being followed-up at the sickle cell centre of the Federal Teaching Hospital, Gombe, northeast Nigeria. We consecutively recruited 294 children aged 2 - 17 years while in steady state from June to November 2017. Quantitative data were collected from parents/caregivers via a researcher administered questionnaire and cholecystosonography performed after a minimum of 8-hour fast. Predictors of Cholelithiasis were examined using binary logistic regression. Results: The mean age of children with sickle cell anaemia was $9.0 \pm 4.5$ years. The prevalence of Cholelithiasis in children with sickle cell anaemia in steady state was $4.8 \%$. Children aged $15-17$ years had 12 times higher odds of having Cholelithiasis [AOR $=12.268$ (95\% CI $=1.3$ 112.8)]. Conclusion: The prevalence of Cholelithiasis in children with sickle cell anaemia though generally low, increases progressively with age to peak during middle to late adolescence.
\end{abstract}

\section{Keywords}

Children, Sickle Cell Anaemia, Cholelithiasis, Northeast Nigeria, Adolescence 


\section{Introduction}

Sickle-cell disease is the most important genetic disorder globally, affecting 5\% of the world's population [1] [2]. An estimated 200,000 children with its most severe form-sickle cell anaemia (SCA) are born in Africa each year [2], of which more than $50 \%$ of these are born in Nigeria [3]. Within the country, the northeast sub-region has the highest burden of the sickle cell trait [4]. Sickle cell anaemia is the most common disease associated with Cholelithiasis in childhood [3].

Several pathophysiological mechanisms underlying the development of Cholelithiasis in childhood SCA have been proposed, notable among which are persistent and accelerated haemolysis [5] [6], gall bladder abnormalities [7] [8], single nucleotide polymorphisms [9] [10] [11], dietary fibre abnormalities [12] [13], biliary sludge [14], and precipitation of polymerized calcium bilirubinate within the gallbladder lumen to form black pigment stones when the ion product of calcium and unconjugated bilirubin exceeds its solubility [15] [16] [17].

The prevalence of Cholelithiasis in children with sickle cell anaemia is reported to be as high as $19 \%$ - $50 \%$ among subjects in Europe, Asia and the Americas [18] [19] [20]; however studies in sub-Saharan Africa [21] [22] [23] have reported a much lower prevalence between $4 \%$ and $8 \%$. The risk of developing Cholelithiasis has been reported to increase with age in children with SCA [21] [24] [25] [26] and though often asymptomatic, the significance of Cholelithiasis lies in its ability to present with abdominal complaints or lead to the development of calculus cholecystitis, both of which may be indistinguishable from vaso-occlusive crises [27]. Calcium bilirubinate stones may also act as a nidus for bacterial infections, thereby predisposing to higher morbidity manifested as both increased hospital for "abdominal crises" and increased ambulatory hospital visits [28].

Despite the high burden of sickle cell anaemia in the sub-region, there is limited knowledge of the prevalence of Cholelithiasis among the affected children. Early identification of children with SCA who have Cholelithiasis reduces the chances of misdiagnosis, mistreatment, and allows for elective cholecystectomy which has better outcomes compared to emergency cholecystectomy [29]. Furthermore, cholecystosonography the diagnostic test of choice is cheap, readily available, free from ionising radiation and has both high sensitivity and specificity [30].

This study sought to determine the prevalence of Cholelithiasis among children with sickle cell anaemia being followed up at a tertiary hospital in northeast Nigeria.

\section{Materials and Methods}

The study was conducted at the Federal Teaching Hospital, Gombe (FTHG) which is a 450-bed tertiary health institution located in Gombe, Gombe state. Gombe State is located in the centre of the northeast region of Nigeria between 
latitudes $90^{\circ} 30^{\prime} \mathrm{N}$ and $12^{\circ} 30^{\prime} \mathrm{N}$, Longitudes $8^{\circ} 5^{\prime}$ and $11^{\circ} 45^{\prime}$ [31] [32].

The regional sickle cell centre located in the Federal Teaching Hospital serves as a referral centre for sickle cell disease management for the northeast. It provides out-patient care for both adults and children with sickle cell diseases from Gombe and neighboring states in the region. The sickle cell centre offers genetic counselling, neonatal screening for sickle cell disease, monitoring including transcranial ultrasonography and referrals. The paediatric clinic is supervised by a Paediatrician trained in sickle cell disease management, resident doctors, nurses and pharmacy and laboratory services. This clinic holds once a week and attends to approximately 60 - 80 paediatric outpatients per clinic with a total of 400 registered patients aged 0 - 17 years at the time of the study. Each child is routinely followed up every three months or more frequently when indicated.

\section{Study Design}

This was a cross-sectional analytic study.

\subsection{Sample Size}

A total of 322 subjects were enrolled as determined using the Fischer formula [33] [34] and after adjusting to account for missing or incomplete data.

\subsection{Study Population}

The study population comprised of children aged 2 - 17 years diagnosed with sickle cell anaemia on follow-up at the sickle cell clinic of the hospital and whose parents/caregivers consented to the study and assent also obtained from children $\geq 7$ years.

\subsection{Sampling Technique}

A consecutive sampling technique was employed where all subjects who met the inclusion criteria were consecutively recruited within the study period of 6 months (June 2017-November 2017) until the sample size was achieved. The use of consecutive sampling was adopted in order to recruit all eligible subjects within the study period since it could not be determined who would be in steady state at each hospital visit.

\subsection{Inclusion \& Exclusion Criteria}

All children aged 2 - 17 years attending the sickle cell clinic of the Federal Teaching Hospital, Gombe who were in steady state and parents/caregivers consented were recruited. Steady state was defined by the absence of infection (indicated by medical history and or clinical evidence), acute complications or crises for at least four weeks and no blood transfusions in the preceding four months [35]. Children $<2$ years (due to the difficulty of ensuring the overnight fast) and those who had had cholecystectomy were excluded. 


\subsection{Ethical Consideration}

Prior to commencement of the study, ethical approval was obtained from the Hospital's Research and Ethics Committee. Data collected was anonymized.

\subsection{Data Collection}

On each clinic day, the children were triaged and those who were acutely ill were referred to the children's emergency. Parents and caregivers who brought their wards for routine follow-up were given information about the study and signed consent was obtained. Parents/caregivers whose children were found eligible for the study and consented were given appointments and guidelines for cholecystosonography. Socio-demographic data of subjects were documented.

\subsection{Diagnosis of Cholelithiasis}

Cholecystosonography was performed on subjects after they had fasted for at least 8 hours using a Phillips HD3 general purpose ultrasound scanner equipped with a $3.5 \mathrm{MHz}$ curvilinear transducer. The procedure was explained to the parent/caregiver and child by the researcher in simple terms. Sonography was carried out on each subject with a parent or caregiver present, and where necessary, holding the child to provide reassurance and comfort. Subjects were scanned in the supine and left lateral decubitus positions. Warm coupling gel was applied at the scan site-usually the right upper quadrant and transducer placed and moved in a transverse plane cranially and caudally to display the liver image which serves as a window to the gallbladder.

The gallbladder was visualized as a sonolucent (dark) "pear" shaped organ at the inferior surface of the liver. Cholelithiasis was identified as curvilinear echogenic structures casting acoustic shadows which moved with a change in scan position [37] [38]. Biliary sludge was identified as sand-like echogenic structures in the gallbladder which move with a change in scan position but do not cast acoustic shadows [36] [37].

\subsection{Data Analysis}

All data generated were processed and analysed using the IBM Corp SPSS statistics for windows version 24.0 [39]. Age was further sub-categorized into four groups, 2 - 5; 6 - 9; 10 - 14 and 15 - 18 years for ease of analysis. Proportions and percentages were computed for categorical variables. The mean age and standard deviations of age was computed.

Fishers' exact test was used when $>20 \%$ of cells contained numbers $<5$. Results were presented in Tables and Figures such as line graphs, and bar charts to aid better presentation of findings.

The prevalence of Cholelithiasis was computed across the population studied. To test the level of significant association noticed across the subgroups, the confidence interval was set at $95 \%$ and p-values $<0.05$ were considered to be statistically significant. Binary logistic regression was employed to determine which 
subject characteristic was most predictive of Cholelithiasis.

\section{Results}

\subsection{Descriptive Characteristics of Study Population}

A total of 322 children who fulfilled the inclusion criteria were recruited. Of these, 294 subjects returned to participate in the study and had their data analysed. The other 28 children were excluded from analysis (22 did not return for the procedure, 6 presented but had acute illnesses and so were referred to the children's emergency).

Males constituted 49\% (144) and females 51\% (150) of study participants. The male-to-female ratio was approximately $1: 1$. The mean age of study subjects was $9.0 \pm 4.5$ years. Females were older than males with mean age of $9.6 \pm 4.4$ years vs $8.5 \pm 4.4$ years for males, and the difference was statistically significant $\mathrm{p}=$ 0.031 .

The 10 - 14 year age category constituted the highest number of study participants $29.9 \%$ (88) followed by the $2-5$ year age category $27.2 \%$ (80). The lowest contributor accounting for $16.0 \%$ (47) of study participants were 15 - 18 years (Table 1).

Five ethnic groups accounted for more than $80 \%$ of study subjects: Hausa $32.7 \%$ (96), Fulani 31.0\% (91), Tera 10.9\% (32), Barebare 4.1\% (12); Tangale $3.4 \%$ (10). There were 27 ethnic nationalities among the study subjects (Figure $1)$.

\subsection{Prevalence of Cholelithiasis among Children with Sickle Cell Anaemia in Steady State}

Among the 294 children with sickle cell anaemia in steady state aged 2 - 17 years, 14 were found to have Cholelithiasis, giving the prevalence as $4.8 \%(14 / 294)$. Biliary sludge was visualized in an additional $2.7 \%(8 / 294)$. The prevalence of Cholelithiasis was similar between male participants $4.9 \%$ (7/144) and females $4.7 \%(7 / 150)(\mathrm{p}=0.938)$.

The 15 - 17 years age category had the highest prevalence of Cholelithiasis $14.9 \%(7 / 47)$ while the 2 - 5 years age category had the lowest prevalence $1.3 \%$ $(1 / 80)$. The prevalence of Cholelithiasis increased with age from $1.3 \%$ at $2-5$

Table 1. Description of study subjects by age-category and sex.

\begin{tabular}{cccc}
\hline & Male $(\mathrm{N}=144)$ & Female $(\mathrm{N}=150)$ & Total $(\mathrm{N}=294)$ \\
\cline { 2 - 3 } Age category (years) & $\mathrm{n}(\%)$ & $\mathrm{n}(\%)$ & $\mathrm{n}(\%)$ \\
\hline $6-5$ & $44(30.5)$ & $36(24.0)$ & $80(27.2)$ \\
$10-14$ & $42(29.2)$ & $37(24.7)$ & $79(26.9)$ \\
$15-17$ & $40(27.8)$ & $48(32.0)$ & $88(29.9)$ \\
& $18(12.5)$ & $29(19.3)$ & $47(16.0)$
\end{tabular}




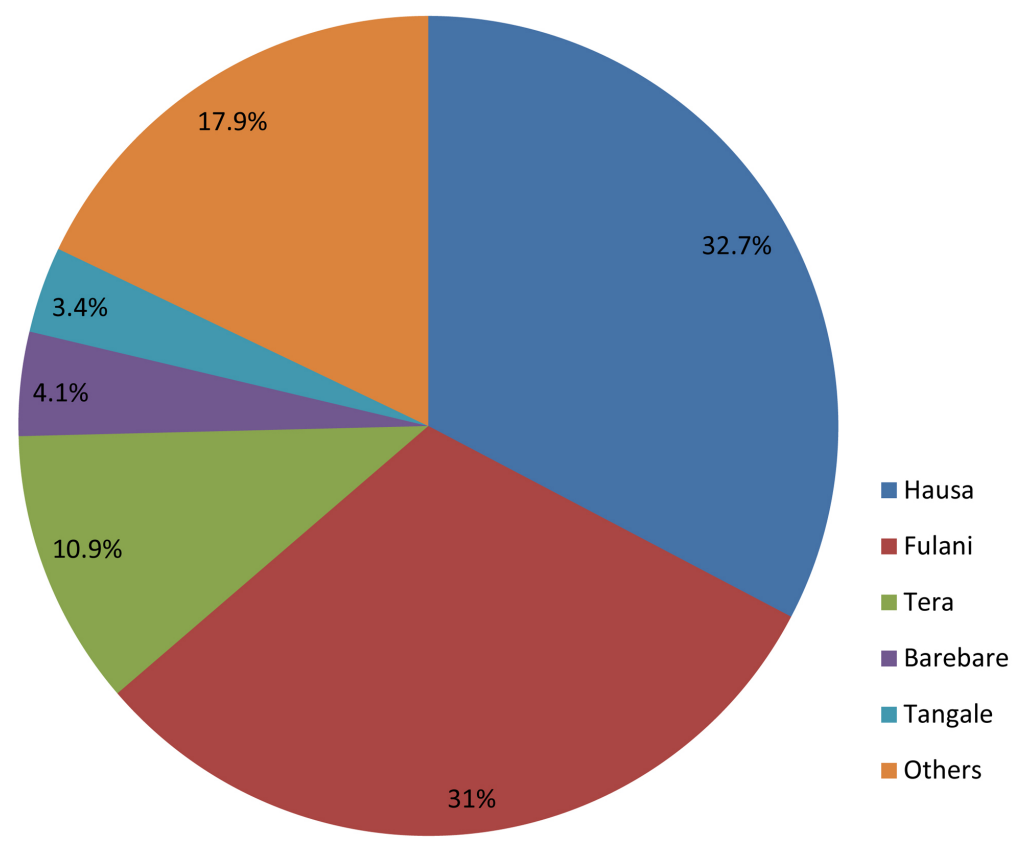

Figure 1. Pie chart showing ethnic distribution of study participants. ${ }^{\star}$ Others: Babur, Bajju, Bolewa, Bura, Buzu, Dadiya, Gizmawa, Gondumawa, Igbira, Jara, Jukun, Kanakuri, Kanuri, Karekare, Kilba, Mangu, Nizom, Pero, Shua, Waja, Wurkun, Yoruba.

years; to $2.5 \%$ at 6 - 9 years and $4.5 \%$ at 10 - 14 years. This difference in prevalence of Cholelithiasis by age category of subjects was statistically significant with $\mathrm{p}<0.001$ (Figure 2).

The prevalence of Cholelithiasis was highest in the Fulani ethnic group 11\% (10/91). Fulani subjects contributed $31 \%$ (91/294) of study participants however, $71.4 \%(10 / 14)$ of children with Cholelithiasis were of Fulani ethnicity. The difference in prevalence of Cholelithiasis based on ethnicity of subjects was statistically significant with $\mathrm{p}=0.012$. No subjects of Hausa, Barebare or Tangale ethnicity had Cholelithiasis (Table 2).

Binary logistic regression indicated that age group was a significant predictor of Cholelithiasis among children with sickle cell anaemia. The odds of having Cholelithiasis were 12times higher in children aged $15-17$ years than those aged 2 - 5 years (CI 1.334 - 112.825). Children of Fulani ethnicity were 2.4 times more likely to have Cholelithiasis than those of other ethnicities (CI 0.590 - 9.758). This finding was however not statistically significant (Table 3).

\subsection{Follow-Up}

At the time of data collection, all participants and their parents/caregivers who were found to have Cholelithiasis were enlightened on the causes, likely symptoms, complications and definitive treatment modality and referred to the paediatric surgical unit for further management. Questions and concerns raised by the parents/caregivers and children were also appropriately addressed. 


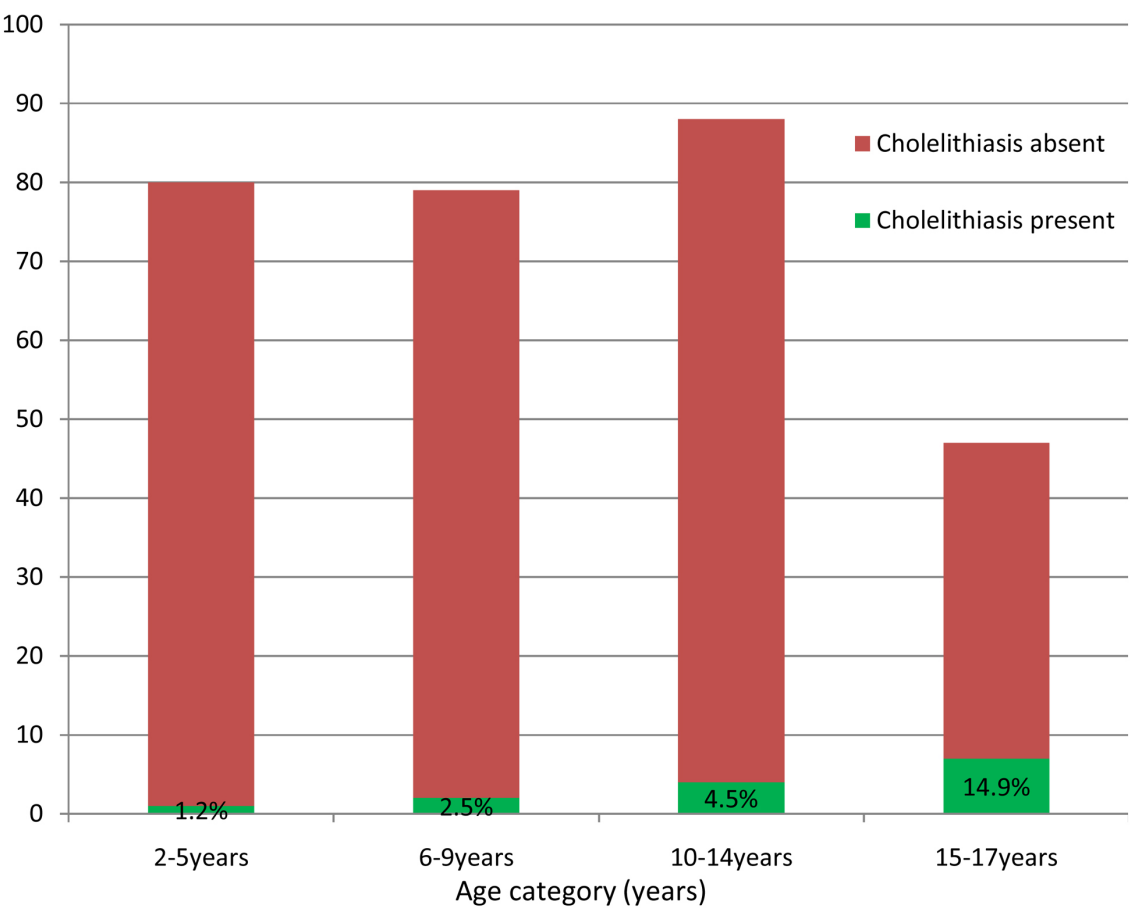

Figure 2. Prevalence of Cholelithiasis by age category of study subjects.

Table 2. Prevalence of gallstone by ethnic group.

\begin{tabular}{ccccccccc}
\hline & Hausa & Fulani & Tera & Barebare & Tangale & Others & Total & \\
Cholelithiasis & $\mathrm{N}=$ & $\mathrm{N}=$ & $\mathrm{N}=$ & $\mathrm{N}=$ & $\mathrm{N}=$ & $\mathrm{N}=$ & & \\
& $96(\%)$ & $91(\%)$ & $32(\%)$ & $12(\%)$ & $10(\%)$ & $53(\%)$ & $\mathrm{N}=294$ & P-value $^{*}$ \\
Yes & $0(0)$ & $10(11)$ & $1(3.1)$ & $0(0)$ & $0(0)$ & $3(5.7)$ & $14(4.8)$ & \\
No & $96(100)$ & $81(89)$ & $31(96.9)$ & $12(100)$ & $10(100)$ & $50(94.3)$ & $280(95.2)$ & $\mathbf{0 . 0 1 2}$ \\
\hline
\end{tabular}

${ }^{\star}$ Fishers' exact test p-value.

Table 3. Binary logistic regression analysis of variables associated with Cholelithiasis in children with sickle cell anaemia.

\begin{tabular}{cccc}
\hline Variable & Odds ratio & $95 \% \mathrm{CI}$ & P-value \\
\hline Age group & & & \\
$2-5$ & 1 & $0.150-20.742$ & 0.653 \\
$6-9$ & 1.762 & $0.404-37.759$ & 0.239 \\
$10-14$ & 3.904 & $1.334-112.825$ & 0.027 \\
$15-17$ & 12.268 & & \\
Ethnic group & & & 0.996 \\
Hausa & 0.000 & $0.590-9.758$ & 0.221 \\
Fulani & 2.399 & $0.048-6.763$ & 0.658 \\
Tera & 0.573 & 0.000 & 0.999 \\
Barebare & 0.000 & 0.000 & 0.999 \\
Tangale & 0.000 & & \\
Others & 1 & & \\
\hline
\end{tabular}




\section{Discussion}

Our study shows a low prevalence of Cholelithiasis (4.8\%) among children with sickle cell anaemia at the Federal Teaching Hospital, Gombe. The prevalence of Cholelithiasis in children with sickle cell anaemia established by this study is a reflection of the generally low prevalence of Cholelithiasis reported by most authors within the country [Adekile et al. [39] (4.4\%), Odunvbun et al. (5\%), [23] Maaji et al. [40] (5.6\%), Nzeh et al. (4.2\%) [22]]. Our findings are also comparable to the low prevalence of $4 \%$ and $9.4 \%$ respectively, reported by Darko et al. [21] and Diagne et al. [41] among Ghanaian and Senegalese children with sickle cell anaemia.

In contrast to our findings, Koueta et al. [42] found the prevalence of Cholelithiasis to be $24.3 \%$ among children with sickle cell anaemia in Burkina Faso (West Africa), despite having a study population and perhaps environmental factors similar to this study. The higher prevalence they reported compared to this and others within sub-Saharan Africa may be attributable to differences in study design; the Burkina Faso study was a 10 year retrospective review of abdominal ultrasound reports from their clinic over ten years. Since abdominal ultrasonography was not routinely done for all children with sickle cell anaemia, the use of ultrasound reports may have skewed the findings in favour of individuals being investigated for abdominal symptoms for which abdominal ultrasonography was requested.

The low prevalence of Cholelithiasis from most cross-sectional studies within the country and sub-Saharan Africa [21] [22] [23] [34] [40] [41] suggests the likelihood of a lower prevalence of Cholelithiasis in children with sickle cell anaemia in the West African sub-region compared to North-Africa [43], Asia [44] [45], Europe [24] and the Americas [18] [20] [46]. Genetic, environmental and lifestyle characteristics of individuals with sickle cell disease within the sub-region when compared to other climes may explain these differences observed.

The predominant diet consumed by most individuals in sub-Saharan Africa has been reported to be high in fibre [13]. High dietary fibre intake may protect against pigment gallstone formation in children with sickle cell anaemia by speeding intestinal transit and the production of abundant short chain fatty acids which diminish intestinal $\mathrm{pH}$, reduce biliary hydrophobic bile acids, precipitate unconjugated bilirubin and sequester bile acids in the large intestine [13] [47]. These beneficial properties of the typical "African diet" may partly explain the lower prevalence of Cholelithiasis among individual residing in sub-Saharan Africa relative to their counterparts in other climes [13] [47]. Large population-based, long-term, prospective epidemiological studies aiming to identify the protective value of dietary components have however been hampered by difficulties in estimating the precise quantity and ingestion pattern of nutrients.

The prevalence of Cholelithiasis among children with sickle cell anaemia at Federal Teaching Hospital, Gombe though higher among male participants, did 
not significantly differ from that observed in their female counterparts. The finding of similar sex occurrence of Cholelithiasis in sickle cell anaemia patients was also reported by Billa et al. [48] in 90 adults and children with sickle cell anaemia in steady state in Yaounde, Cameroun. The age range of subjects was 15 45 years and 53\% (48) were 15 - 20 years. Martins et al. [49] also found a similar equal male: female ratio of Cholelithiasis in a retrospective descriptive study of cholecystosonography findings of all children and adults with sickle cell disease who were on follow-up at their Teaching Hospital in Brazil (South America). However, in contrast to these findings, researchers [23] in Benin, South-south Nigeria have reported a wide variation in male: female ratio of 4:1 in their study using ultrasonography to screen children aged $1-18$ years with sickle cell anaemia for Cholelithiasis.

This study shows a pattern of increasing prevalence of Cholelithiasis with age in children with sickle cell anaemia from $1.3 \%$ below 5 years to $14.9 \%$ in mid-to-late adolescence. These findings are comparable to reports by other researchers [18] [21] of very low prevalence of Cholelithiasis below 5 years which increases steadily throughout childhood to peak in late adolescence. In sickle cell anaemia, like many other disorders associated with chronic haemolysis, Cholelithiasis is the end result of a pathologic process in consisting wholly or partially of persistent hyperbilirubinaemia [17] [50], gall bladder dysfunction; genetic defects in UGT activity [9] [10] [11]; biliary sludge formation [14] [50] and subsequent calcium deposition to produce pigment gallstones [17] [50]. The cumulative likelihood of these events therefore increases progressively with age and biliary sludge has been reported to be a well-known pre-Cholelithiasis phenomenon [14]. Our study however has an advantage of having adjusted for other variables like sex and ethnicity; with age remaining the only predictor of Cholelithiasis among children with sickle cell anaemia. This uniformity across many studies, showing increasing prevalence of Cholelithiasis with age, among children in sickle cell anaemia may also serve as a guide towards the development of guidelines for routine screening for Cholelithiasis in this sub-population of children.

Children of Fulani ethnicity appeared to be slightly more affected by Cholelithiasis than other ethnicities. Few studies (if any) have established a relationship between ethnicity and the pigment type Cholelithiasis commonly found in sickle cell anaemia. The diet of most Fulani's has been reported to be identical to those of the sedentary communities who reside closely with them although they may also consume high amounts of milk [51]. Glew et al. [52] reported low LDL cholesterol, normal (Total and HDL) cholesterol and triglycerides in pastoral Fulani despite diets found to be high in saturated fat. The role of ethnic differences in predisposition to Cholelithiasis in sickle cell anaemia is therefore unclear.

Our study is limited by our inability to determine symptomatology of Cholelithiasis in affected children, in order to look into features which may have been associated with the presence of Cholelithiasis. Also our non-inclusion of variables such as weight in our study raises the possibility of the occurrence of 
adiposity-related cholesterol Cholelithiasis.

\section{Conclusion}

This study found a low prevalence of Cholelithiasis among children with sickle cell anaemia steady state at the Federal Teaching Hospital, Gombe. The prevalence of Cholelithiasis increases with age and the Fulani children have a higher prevalence than other ethnic groups.

\section{Acknowledgements}

The authors would like to acknowledge the staff of the Sickle cell centre, Federal Teaching Hospital Gombe for their contributions to the success of this study. Parents/caregivers and children with sickle cell anaemia are appreciated for participating.

\section{Conflicts of Interest}

There are no competing interests.

\section{Ethical Approvals}

The institutional review board at the Federal Teaching Hospital Gombe reviewed and approved the study protocol.

\section{Funding}

We have no external funding or conflict of interest to declare.

\section{Author Contributions}

AA: Conceived of the study and study design, designed the data collection tool, performed cholecystosonography, conducted quantitative data analysis, developed the first manuscript draft, and critically reviewed the final manuscript;

IJ: Oversaw the study design and critically reviewed and commented on all drafts of the manuscript;

STS: Oversaw the study design and critically reviewed and commented on all drafts of the manuscript.

\section{References}

[1] Piel, F.B., Hay, S.I., Gupta, S., Weatherall, D.J. and Williams, T.N. (2013) Global Burden of Sickle Cell Anaemia in Children under Five, 2010-2050; Modelling Based on Demographic, Excess Mortality and Interventions. PLoS Medicine, 10, e1001484. https://doi.org/10.1371/journal.pmed.1001484

[2] World Health Organization (2006) Sickle-Cell Anaemia. Fifty-Ninth World Health Assembly, Provisional Agenda Item 11.4, A59/9.

[3] Serjeant, G.R. (1997) Sickle Cell Disease. Lancet, 350, 725-730. https://doi.org/10.1016/S0140-6736(97)07330-3

[4] Ambe, J.P. (2012) Clinical Features of Sickle Cell Anaemia in Northern Nigerian 
Children. West African Journal of Medicine, 31, 81-85.

[5] Oluwatoyin Ilesanmi, O.O. (2010) Haematological Basis of Symptoms and Crises in Sickle Cell Disorder: Implications for Counselling and Psychotherapy. Hematology Reports, 26, e2. https://doi.org/10.4081/hr.2010.e2

[6] Rees, D.C., Williams, T.N. and Gladwin, M.T. (2010) Sickle-Cell Disease. Lancet, 376, 2018-2031. https://doi.org/10.1016/S0140-6736(10)61029-X

[7] Everson, G.T., Nemeth, A., Kourourian, S., Zogg, D., Leff, N.B., Dixon, D., et al. (1989) Gall Bladder Function Is Altered in Sickle Hemoglobinopathy. Gastroenterology, 96, 1307-1316. https://doi.org/10.1016/S0016-5085(89)80018-6

[8] Sugo, T., Hakamada, K., Narumi, S. and Sasaki, M. (2008) Decreased Postprandial Gallbladder Emptying in Patients with Black Pigment Stones. World Journal of Gastroenterology, 14, 2825-2831. https://doi.org/10.3748/wjg.14.2825

[9] Milton, J.N., Sebastiani, P., Solovieff, N., Hartley, S.W., Bhatnagar, P. and Arking, D.E. (2012) A Genome-Wide Association Study of Total Bilirubin and Cholelithiasis Risk in Sickle Cell Anemia. PLoS ONE, 7, e34741. https://doi.org/10.1371/journal.pone.0034741

[10] Chaar, V., Kećlard, L., Diara, J.P., Leturdu, C., Elion, J., Krishnamoorthy, R., et al. (2005) Association of UGT1A1 Polymorphism with Prevalence and Age at Onset of Cholelithiasis in Sickle Cell Anaemia. Haematologica, 90, 188-199.

[11] Carpenter, S.L., Lieff, S., Howard, T.A., Eggleston, B. and Ware, R.E. (2008) UGT1A1 Promoter Polymorphisms and the Development of Hyperbilirubinemia and Gallbladder Disease in Children with Sickle Cell Anemia. American Journal of Hematology, 83, 800-803. https://doi.org/10.1002/ajh.21264

[12] Njeze, G.E. (2013) Gallstones. Nigerian Journal of Surgery, 19, 49-55.

[13] Stinton, L.M. and Shaffer, E.A. (2012) Epidemiology of Gallbladder Disease: Cholelithiasis and Cancer. Gut Liver, 6, 172-187. https://doi.org/10.5009/gnl.2012.6.2.172

[14] Shaffer, E.A. (2001) Gallbladder Sludge: What Is Its Clinical Significance? Current Gastroenterology Reports, 3, 166-173. https://doi.org/10.1007/s11894-001-0015-6

[15] Weerakoon, H.T., Ranasinghe, J.G., Navaratna, A., Sivakanesan, R., Galketiya, K.B. and Rosairo, S. (2014) Can the Type of Gallstones Be Predicted with Known Possible Risk Factors? A Comparison between Mixed Cholesterol and Black Pigment Stones. BMC Gastroenterology, 14, 88. https://doi.org/10.1186/1471-230X-14-88

[16] Sticova, E. and Jirsa, M. (2013) New Insights in Bilirubin Metabolism and Their Clinical Implications. World Journal of Gastroenterology, 19, 6398-6407. https://doi.org/10.3748/wjg.v19.i38.6398

[17] Vitek, L. and Carey, M.C. (2012) New Pathophysiological Concepts Underlying Pathogenesis of Pigment Gallstones. Clinics and Research in Hepatology and Gastroenterology, 36, 122-129. https://doi.org/10.1016/j.clinre.2011.08.010

[18] Gumiero, A.P., Bellomo-Brandão, M.A. and Costa-Pinto, E.A. (2008) Gallstones in Children with Sickle Cell Disease Followed up at a Brazilian Hematology Center. Arquivos de Gastroenterologia, 45, 313-318. https://doi.org/10.1590/S0004-28032008000400010

[19] Al-Salem, A.H. and Qaisruddin, T.S. (1998) The Significance of Biliary Sludge in Children with Sickle Cell Disease. Pediatric Surgery International, 13, 14-16. https://doi.org/10.1007/s003830050233

[20] Webb, D.K., Darby, J.S., Dunn, D.T., Terry, S.I. and Serjeant, G.R. (1989) Gall Stones in Jamaican Children with Homozygous Sickle Cell Disease. Archives of Disease in Childhood, 64, 693-696. https://doi.org/10.1136/adc.64.5.693 
[21] Darko, R., Rodrigues, O.P. and Oliver-Commey, J.O. (2005) Gallstones in Ghanaian Children with Sickle Cell Disease. West African Journal of Medicine, 24, 295-298.

[22] Nzeh, D.A. and Adedoyin, M.A. (1989) Sonographic Pattern of Gallbladder Disease in Children with Sickle Cell Anaemia. Pediatric Radiology, 19, 290-292. https://doi.org/10.1007/BF02467294

[23] Odunvbun, M.E. and Adeyekun, A.A. (2014) Ultrasonic Assessment of the Prevalence of Gallstones in Sickle Cell Disease Children Seen at the University of Benin Teaching Hospital, Benin City, Nigeria. Nigerian Journal of Paediatrics, 41, 370-374. https://doi.org/10.4314/njp.v41i4.16

[24] Parez, N., Quinet, B., Grimprel, E., Larroquet, M., Audry, G. and Begue, P. (2001) Cholelithiasis in Children with Sickle Cell Anemia: Experience of a French Pediatric Hospital. Archives de Pédiatrie, 8, 1045-1049. https://doi.org/10.1016/S0929-693X(01)00581-4

[25] Longo-Mbenza, B., Ngiyulu, R., Kizunda, P., Kaluila, M. and Bikangi, N. (2004) Gall Bladder Disease in Young Congolese with Sickle Cell Anaemia: An Ultrasound Survey. Journal of Tropical Pediatrics, 50, 73-77.

https://doi.org/10.1093/tropej/50.2.73

[26] Agholor, C.A., Akhigbe, A.O. and Atalabi, O.M. (2014) The Prevalence of Cholelithiasis in Nigerians as Diagnosed by Ultrasound. British Journal of Medicine and Medical Research, 4, 2866-2872. https://doi.org/10.9734/BJMMR/2014/8645

[27] Ariyan, S., Shessel, F.S. and Picket, L.K. (1976) Cholecystitis and Cholelithiasis Masking as Abdominal Crises in Sickle Cell Disease. Pediatrics, 58, 252.

[28] Alexander-Reindorf, C., Nwaneri, R.U., Worrell, R.G., Ogbonna, A. and Uzoma, C. (1990) The Significance of Gallstones in Children with Sickle Cell Anemia. Journal of the National Medical Association, 82, 645-650.

[29] Currò, G., Meo, A., Ippolito, D., Pusiol, A. and Cucinotta, E. (2007) Asymptomatic Cholelithiasis in Children with Sickle Cell Disease. Early or Delayed Cholecystectomy? Annals of Surgery, 245, 126-129. https://doi.org/10.1097/01.sla.0000242716.66878.23

[30] European Association for the Study of the Liver (EASL) (2016) Clinical Practice Guideline on the Prevention, Diagnosis and Treatment of Gallstones. Journal of Hepatology, 65, 146-181. https://doi.org/10.1016/j.jhep.2016.03.005

[31] Gombe State Nigeria (2016) General Information. http://www.gombestategov.ng/geninformation.html

[32] Federal Republic of Nigeria (2009) Legal Notice on Publication of 2006 Census Final Results. Federal Republic of Nigeria Official Gazette, 96, B28.

[33] Araoye, M.O. (2003) Sample Size Determination. In: Araoye, M.O., Ed., Research Methodology with Statistics for Health and Social Sciences, Nathadex, Ilorin.

[34] Naing, L., Winn, T. and Rusli, B.N. (2006) Practical Issues in Calculating Sample Size for Prevalence Studies. Archives of Orofacial Sciences, 1, 9-14.

[35] Ballard, S.K. (2012) More Definitions in Sickle Cell Disease: Steady State vs. Base Line Data. American Journal of Hematology, 87, 338. https://doi.org/10.1002/ajh.22259

[36] Gonzalez, L. and MacIntyre, W.J. (1980) Acoustic Shadow Formation by Gallstones. Radiology, 135, 217-218. https://doi.org/10.1148/radiology.135.1.7360964

[37] Walker, J., Chalmers, R.T. and Allan, P.L. (1992) An Audit of Ultrasound Diagnosis of Gallbladder Calculi. The British Journal of Radiology, 65, 581-584.

https://doi.org/10.1259/0007-1285-65-775-581 
[38] IBM Corp. (2015) IBM SPSS Statistics for Windows, Version 24.0. IBM Corp., Armonk.

[39] Adekile, A.D. and Makanjuola, D. (1983) Ultrasonography in Children with Sickle Cell Anemia. Nigerian Journal of Paediatrics, 10, 35-38.

[40] Ma'aji, S.M., Jiya, N.M., Saidu, S.A., Danfulani, M., Yunusa, G.H. and Sani, U.M. (2012) Transabdominal Ultrasonographic Findings in Children with Sickle Cell Anemia in Sokoto, North-Western Nigeria. Nigerian Journal of Basic and Clinical Sciences, 9, 14-17.

[41] Diagne, I., Badiane, M., Moreira, C., Signate-Sy, H., Ndiaye, O., Lopez-Sall, P., et al. (1999) Cholelithiasis and Homozygous Drepanocytosis in Children in Dakar (Senegal). Archives de Pédiatrie, 6, 1286-1292. https://doi.org/10.1016/S0929-693X(00)88890-9

[42] Kouéta, F., Kaboret, S., Yonaba, C., Kaboré, A., Dao, L., Daïla, S.W.T., et al. (2015) Cholelithiasis in Children with Sickle Cell Disease in Ouagadougou Pediatric Hospital. OJP, 5, 256-262.

[43] Attalla, B.A., Karrar, Z.A., Ibnouf, G., Mohamed, A.O., Abdelwahab, O., Nasir, E.M., et al. (2013) Outcome of Cholelithiasis in Sudanese Children with Sickle Cell Anaemia (SCA) after 13 Years Follow-Up. African Health Sciences, 13, 154-159. https://doi.org/10.4314/ahs.v13i1.21

[44] Issa, H. and Al-Salem, A.H. (2010) Hepatobiliary Manifestations of Sickle Cell Anemia. Gastroenterology Research, 3, 1-8. https://doi.org/10.4021/gr2010.01.1332

[45] Kamble, M.B. and Dhanve, V. (2009) Cholelithiasis in Children with Sickle Cell Anaemia in Rural and Tribal Central India. Nigerian Journal of Paediatrics, 36, 60-64.

[46] Walker, T.M., Hambleton, I.R. and Serjeant, G.R. (2000) Gallstones in Sickle Cell Disease: Observations from the Jamaican Cohort Study. The Journal of Pediatrics, 136, 80-85. https://doi.org/10.1016/S0022-3476(00)90054-4

[47] Tsai, C.J., Leitzmann, M.F., Willett, W.C. and Giovannucci, E.L. (2004) Long-Term Intake of Dietary Fibre and Decreased Risk of Cholecystectomy in Women. The American Journal of Gastroenterology, 99, 1364-1370. https://doi.org/10.1111/j.1572-0241.2004.30153.x

[48] Billa, R.F., Biwole, M.S., Juimo, A.G., Bejanga, B. and Blacket, K. (1991) Gallstone Disease in African Patients with Sickle Cell Anaemia: A Preliminary Report from Yaounde, Cameroun. Gut, 32, 539-541. https://doi.org/10.1136/gut.32.5.539

[49] Martins, R.A., Soares, R.S., De Vito, F.B., Barbosa, V.D., Silva, S.S., Moraes-Souza, H., et al. (2017) Cholelithiasis and Its Complications in Sickle Cell Disease in a University Hospital. Revista Brasileira de Hematologia e Hemoterapia, 39, 28-31. https://doi.org/10.1016/j.bjhh.2016.09.009

[50] Venneman, N.G. and van Erpecum, K.J. (2010) Pathogenesis of Gallstones. Gastroenterology Clinics of North America, 39, 171-183.

https://doi.org/10.1016/j.gtc.2010.02.010

[51] University of Missouri: Database for Indigenous Cultural Evolution (DICE): Fulani. http://dice/Missouri.edu/docs/niger-congo/Fulani.pdf

[52] Glew, R.H., Williams, M., Conn, C.A., Cadena, S.M., Crossey, M., Okolo, S.N., et al. (2001) Cardiovascular Disease Risk Factors and Diet of Fulani Pastoralists of Northern Nigeria. The American Journal of Clinical Nutrition, 74, 730-736.

https://doi.org/10.1093/ajcn/74.6.730 


\section{Abbreviations}

$\begin{array}{ll}\text { AOR } & \text { Adjusted odds ratio } \\ \text { CI } & \text { Confidence interval } \\ \text { HDL } & \text { High density lipoprotein } \\ \text { LDL } & \text { Low density lipoprotein } \\ \text { SCA } & \text { Sickle cell anaemia } \\ \text { SD } & \text { Standard deviation } \\ \text { UGT } & \text { Uridyl glucoronosyl transferase }\end{array}$

